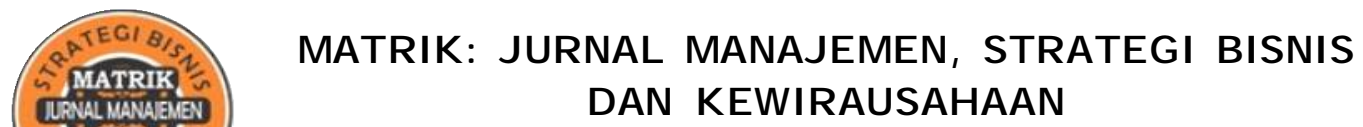

Homepage: https://ojs.unud.ac.id/index.php/jmbk/index

Vol. 13 No. 2, Agustus 2019, 243 - 256

\title{
Pengaruh Kinerja Keuangan, Tata Kelola Perusahaan dan Penggunaan Derivatif Terhadap Risiko Perusahaan
}

\author{
Made Reina Candradewi ${ }^{1)}$, Henny Rahyuda ${ }^{2)}$ \\ ${ }^{1,2)}$ Fakultas Ekonomi dan Bisnis, Universitas Udayana \\ email: reinacandradewi@yahoo.com
}

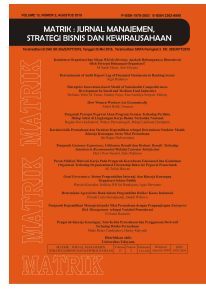

DOI : https://doi.org/10.24843/MATRIK:JMBK.2019.v13.i02.p12

\begin{abstract}
ABSTRAK
Penelitian ini bertujuan untuk mengetahui pengaruh kinerja keuangan, tata kelola perusahaan dan penggunaan derivatif terhadap risiko perusahaan pada perusahaan non-keuangan yang terdaftar di Indeks Kompas100 Bursa Efek Indonesia (BEI). Penelitian ini menggunakan enam variabel bebas yang berpengaruh terhadap risiko perusahaan yaitu likuiditas, solvabilitas, profitabilitas, proporsi komisaris independen, kepemilikan manajerial dan penggunaan derivatif. Populasi dalam penelitian ini adalah seluruh perusahaan non-keuangan yang terdaftar pada indeks Kompas 100 di BEI pada tahun 2017 yang berjumlah 85 perusahaan. Teknik penentuan sampel yaitu dengan purposive sampling method, sehingga sampel akhir pada penelitian ini adalah 74 perusahaan. Teknik analisis data yang digunakan dalam penelitian ini adalah analisis regresi linear berganda. Temuan utama penelitian menunjukkan bahwa solvabilitas berpengaruh secara positif dan signifikan terhadap risiko perusahaan, profitabilitas berpengaruh secara negatif dan signifikan terhadap risiko perusahaan dan penggunaan derivatif berpengaruh negatif dan signifikan terhadap risiko perusahaan. Kata kunci: kinerja keuangan, penggunaan derivatif, risiko perusahaan, tata kelola perusahaan
\end{abstract}

\section{The Effect of Financial Performance, Corporate Governance and Derivatives on Company Risk}

\section{ABSTRACT}

This study aims to determine the effect of financial performance, corporate governance and derivatives usage on firm risk of non-financial companies listed in Kompas100 index at Indonesia Stock Exchange (IDX). This study employs six important independent variables that influence the firm risk, including liquidity, leverage, profitability, the proportion of independent commissioners and derivatives usage. The population in this study are all non-financial companies listed on the Kompas 100 index in 2017 which amounted to 85 companies. This study uses purposive sampling method and the final sample is 74 companies. Data analysis technique used in this study is multiple linear regression analysis. Key research findings in this study indicate that leverage has significant and positive effect on firms risk, profitability has significant and negative effect on firms risk and derivatives usage has negative and significant effect on firms risk.

Keywords: financial performance, derivatives usage, firm risk, corporate governance

\section{PENDAHULUAN}

Pasar modal memiliki peran yang sangat penting bagi perekonomian suatu negara. Pasar modal Indonesia menunjukkan perkembangan tiap tahunnya, hal ini dapat terlihat dari meningkatnya jumlah perusahaan yang terdaftar di pasar modal Indonesia, Bursa Efek Indonesia (BEI). Pada tahun 2017, sejumlah 519 perusahaan telah terdaftar di BEI. Namun saat ini, yang menjadi tantangan utama bagi perusahaan-perusahaan di BEI adalah bagaimana perusahaan mampu menghadapi globalisasi, liberalisasi dunia dan teknologi yang semakin maju. Ketiga hal tersebut dapat menjadi ancaman besar bagi perusahaan karena merupakan faktor pendorong peningkatan risiko yang dihadapi (Hanafi, 2014).

Perusahaan saat ini memiliki berbagai macam risiko yang harus dihadapi seperti risiko perubahan tingkat bunga, risiko nilai tukar, risiko pasar, risiko kredit, risiko operasional, risiko teknologi, risiko likuidasi, risiko perubahan harga komoditas, risiko terjadinya krisis keuangan global dan lainnya (A. 
Saunders dan Cornett, 2014). Risiko tersebut bisa terjadi kapan saja dan sulit untuk dihindari. Semua risiko yang dihadapi oleh perusahaan akan tercermin pada volatilitas nilai perusahaan (Guay, 1999). Bartram et al. (2009) menjelaskan risiko perusahaan secara agregat dapat diukur dengan menghitung volatilitas returns saham perusahaan. Penelitian ini akan menggunakan volatilitas return saham untuk mengukur risiko perusahaan secara agregat.

Kinerja keuangan, tata kelola perusahaan dan penggunaan derivatif merupakan faktor-faktor penting yang dapat mempengaruhi risiko perusahaan ((Borokhovich et al., 2004; Biase dan D“Apolito, 2012; Lantara, 2010; Tsorhe et al., 2011; Trinh et $a l .$, 2015). Kinerja keuangan mencerminkan kondisi kesehatan keuangan perusahaan dalam hal likuiditas, profitabilitas dan solvabilitas. Indikator penting dari tata kelola perusahaan yang perlu diperhatikan dalam pengaruhnya terhadap risiko perusahaan yaitu kepemilikan manajerial dan proporsi komisaris independen. Selain itu, pelaksanaan manajemen risiko dengan menggunakan produk derivatif bermanfaat dalam menurunkan risiko perusahaan.

Penelitian mendalam mengenai bagaimana pengaruh kinerja keuangan, tata kelola perusahaan dan penggunaan derivatif dalam mempengaruhi risiko perusahaan masih sangat diperlukan di Indonesia. Sampai saat ini belum ada penelitian yang menggunakan ketiga faktor penting ini dalam mempengaruhi risiko perusahaan. Penelitianpenelitian sebelumnya juga lebih tertarik untuk meneliti mengenai risiko perusahaan di negara maju. Indonesia merupakan pasar keuangan negara berkembang, maka tentu akan sangat menarik jika penelitian ini dilakukan di Indonesia.

Penelitian ini berupaya memberikan kontribusi pada keilmuan corporate governance framework dengan cara mengisi celah-celah (gaps) penting yang masih ada di literatur. Celah tersebut akan diisi dengan cara menganalisis secara komprehensif mengenai pengaruh kinerja keuangan, tata kelola perusahaan dan penggunaan derivative terhadap risiko perusahaan, yang diharapkan akan mampu meningkatkan pemahaman perusahaan dalam penerapan manajemen risiko perusahaan. Kontribusi ini diharapkan dapat membantu akademisi untuk mengembangkan keilmuan manajemen perusahaan dan memberikan informasi-informasi yang bermanfaat bagi perusahaan saat pelaksanaan manajemen risiko, khususnya bagi perusahaan yang terdaftar di pasar modal negara berkembang, Indonesia.
Secara sederhana risiko dapat didefinisikan sebagai suatu kejadian yang merugikan (Hanafi, 2014). Risiko merupakan suatu ketidakpastian tentang pengembalian aktual yang akan diperoleh dari suatu investasi. Oleh karena itu, dapat disimpulkan bahwa risiko menunjukkan adanya kemungkinan dari suatu kejadian yang memberikan ketidakpastian terhadap return yang diharapkan dan tujuan yang ingin dicapai. Menurut Hanafi (2014), risiko bisa dikelompokkan menjadi dua tipe risiko yaitu risiko murni dan risiko spekulatif. Risiko murni (pure risk) adalah risiko dimana kemungkinan kerugian ada, tetapi kemungkinan keuntungan tidak ada. Risiko spekulatif adalah risiko dimana kita mengharapkan terjadinya kerugian dan juga keuntungan. Sedangkan menurut Van Horne, et al. (2008) risiko perusahaan dikategorikan menjadi tiga jenis risiko: business risk, financial risk dan total risk.

Risiko ada dimana-mana dan sulit untuk dihindari. Risiko tidak bisa dihilangkan atau diciptakan, tetapi risiko hanya bisa ditransfer dari satu pihak ke pihak lainnya. Perusahaan memerlukan manajemen risiko yang bertujuan untuk menciptakan sistem atau mekanisme dalam perusahaan sehingga risiko yang bisa merugikan perusahaan bisa diantisipasi dan dikelola (Hanafi, 2014). Pelaksanaan manajemen risiko oleh perusahaan bertujuan untuk mengelola risiko perusahaan secara agregat. Risiko perusahaan secara agregat ini tercermin dari volatilitas nilai perusahaan, dimana risiko ini hanya dapat diukur dengan menghitung volatilitas stock returns perusahaan (Guay, 1999). Oleh karena itu, risiko perusahaan yang dimaksud dalam penelitian ini adalah volatilitas daily stock returns selama satu tahun pada perusahaan di pasar modal Indonesia.

Kinerja keuangan merupakan suatu penentuan secara periodik mengenai efektivitas operasional organisasi dan tenaga kerjanya berdasarkan sasaran, standar dan kriteria yang ditetapkan sebelumnya (Mulyadi, 2008). Fahmi (2011) menjelaskan bahwa kinerja keuangan adalah suatu analisis yang dilakukan untuk melihat sejauh mana suatu perusahaan telah melaksanakan dengan menggunakan aturan-aturan pelaksanaan keuangan secara baik dan benar. Pengukuran kinerja keuangan sangat penting bagi perusahaan untuk menentukan seberapa baik kegiatan-kegiatan bisnis yang dilaksanakan untuk mencapai tujuan yang telah ditetapkan perusahaan. Pengukuran kinerja keuangan dapat digunakan sebagai acuan untuk melaksanakan perbaikan dan penyempurnaan kegiatan bisnis perusahaan secara berkesinambungan. Menurut Munawir (2010) 
pengukuran kinerja keuangan bertujuan untuk mengetahui tingkat likuiditas, solvabilitas dan profitabilitas perusahaan. Oleh karena itu, pengukuran kinerja keuangan perusahaan dilakukan dengan cara menganalisis laporan keuangan perusahaan yaitu dengan menghitung rasio keuangan.

Rasio keuangan yang mengukur kinerja keuangan dapat diklasifikasikan menjadi lima tipe (Brealey et al., 2014; Brigham et al., 2007; Van Horne et al., 2008; Subramanian dan Paramasivan, 2009) yaitu liquidity ratio, leverage ratio, profitability, activity ratio dan market value ratio. Dalam analisis yang faktor yang berpengaruh terhadap risiko perusahaan, digunakan tiga kinerja keuangan yang paling penting yaitu likuiditas, profitabilitas dan solvabilitas.

Rasio likuiditas mencerminkan kemampuan perusahaan untuk memenuhi kebutuhan jangka pendeknya dengan menggunakan aktiva lancar yang dimiliki perusahaan. Tingkat rasio likuiditas perusahaan yang rendah menunjukkan ketidak mampuan perusahaan untuk memenuhi kebutuhan jangka pendeknya (Van Horne et al., 2008). Dapat dicermati bahwa rendahnya tingkat likuiditas suatu perusahaan menunjukkan kinerja keuangan perusahaan yang kurang baik. Ketika perusahaan memiliki tingkat likuiditas yang tinggi, hal ini menunjukkan bahwa perusahaan tersebut tidak memiliki masalah keuangan, sehingga risiko perusahaan menurun. Beaver et al. (1970)meneliti pengaruh faktor pasar dan faktor akuntansi terhadap risiko sistematik perusahaan dan menemukan korelasi signifikan yang negatif antara tingkat likuiditas dan risiko sistematik perusahaan. Penelitian empiris oleh Biase dan D'Apolito (2012) menemukan bukti bahwa tingkat likuiditas berpengaruh secara negatif dan signifikan terhadap risiko pada perusahaan bank di negara Italia. Oleh karena itu, hipotesis 1 adalah likuiditas berpengaruh negatif dan signifikan terhadap risiko perusahaan.

Tingkat rasio solvabilitas perusahaan menunjukkan seberapa besar perusahaan menggunakan dana pinjaman untuk membiayai aktiva yang dimiliki perusahaan. Ketika perusahaan memiliki tingkat solvabilitas yang tinggi, ini berarti perusahaan memiliki tingkat hutang yang tinggi. Perusahaan yang memiliki tingkat hutang yang besar pada struktur modalnya, maka perusahaan mengalami peningkatan biaya financial distress yang pada nantinya berhubungan dengan peningkatan risiko yang dihadapi perusahaan (Hardwick dan Adams, 1999). Penelitian empiris oleh Mandelker dan Rhee (1984) menemukan bahwa leverage mempunyai pengaruh positif pada risiko sistematik perusahaan. Selanjutnya, Biase dan D“Apolito (2012) menegaskan bahwa leverage dan risiko sistematik memiliki hubungan positif yang kuat. Dengan demikian, hipotesis 2 adalah solvabilitas berpengaruh positif dan signifikan terhadap risiko perusahaan.

Van Horne et al. (2008) menjelaskan bahwa rasio profitabilitas perusahaan menunjukkan kemampuan suatu perusahaan untuk menghasilkan laba bersih. Ketika perusahaan mampu menghasilkan laba bersih yang positif, hal ini berarti perusahaan mampu untuk berinvestasi dengan baik dan menekan biaya operasional dengan efektif. Dengan demikian, tingginya tingkat rasio profitabilitas menunjukkan perusahaan tidak memiliki permasalahan keuangan yang signifikan. Selain itu peningkatan profitabilitas juga menunjukkan perusahaan tersebut memiliki kinerja yang baik sehingga risiko perusahaan cenderung rendah. Chun dan Ramasamy (1989) melakukan penelitian mengenai pengaruh variabel akuntansi terhadap risiko sistematik perusahaan di Malaysia. Mereka menemukan bahwa tingkat profitabilitas merupakan faktor yang paling penting dalam mempengaruhi risiko sistematik perusahaan. Selain itu, hubungan yang negatif dan signifikan antara profitabilitas dengan risiko sistematik juga ditemukan oleh Biase dan D“Apolito (2012) pada perusahan bank di Italia. Oleh karena itu, hipotesis 3 adalah profitabilitas berpengaruh negatif dan signifikan terhadap risiko perusahaan

Tata kelola perusahaan merupakan suatu struktur yang terdiri dari pemegang saham, dewan direksi, dewan komisaris, dan hirarki manajerial perusahaan. Tata kelola perusahaan ini melibatkan serangkaian hubungan antara pemegang saham, dewan direksi, dewan komisaris, manajemen dan pemangku kepentingan lainnya (OECD, 2014). Menurut Forum for Corporate Governance in Indonesia (selanjutnya, FCGI) (2016), tata kelola perusahaan adalah seperangkat aturan yang mendefinisikan hubungan antara pemegang saham, manajer, kreditor, pemerintah, karyawan dan stakeholder internal dan eksternal lainnya yang berkaitan dengan hak-hak dan tanggung jawab mereka, atau sistem dimana perusahaan diarahkan dan dikendalikan. Dengan kata lain, tata kelola perusahaan merupakan suatu sistem yang mengatur hubungan antara shareholders, dewan direksi, dewan komisaris, manajer, kreditor, pemerintah, karyawan dan seluruh stakeholder di perusahaan. 
Fungsi tata kelola perusahaan adalah untuk memacu penggunaan sumber daya perusahaan secara efisien dimana sangat diperlukan akuntabilitas dalam pengelolaan sumber daya tersebut (Osuoha, 2013). Selain itu, tujuan utama penerapan tata kelola perusahaan adalah untuk menciptakan nilai tambah bagi para pemangku kepentingan atau stakeholders (FCGI, 2016). Sistem tata kelola perusahaan yang baik harus memberikan perlindungan yang efektif bagi pemegang saham dan kreditur, sehingga mereka dapat meyakinkan diri untuk mendapatkan pengembalian yang tepat atas investasi mereka. Hal ini juga akan membantu untuk menciptakan lingkungan yang kondusif, pertumbuhan yang efisien dan berkelanjutan bagi perusahaan.

Tata kelola perusahaan merupakan suatu framework yang melibatkan hubungan antara pemegang saham, direksi, dewan komisaris, manajemen dan pemangku kepentingan lainnya (OECD, 2014). Tata kelola perusahaan sangat bermanfaat untuk memacu penggunaan sumber daya perusahaan secara efisien sehingga perusahaan mampu beroperasi dengan baik (Osuoha, 2013). Selain itu penerapan tata kelola perusahaan yang baik dapat menurunkan agency problem (Welker, 1995) dan meningkatkan kualitas pengawasan perusahaan (C. L. et al., 2014) sehingga perusahaan mampu berkinerja dengan baik. Pelaksanaan tata kelola perusahaan yang baik, akan mampu menekan risiko perusahaan. Indikator dari tata kelola perusahaan yang perlu dicermati yaitu proporsi kepemilikan manajerial dan proporsi komisaris independen.

Kepemilikan manajerial yang ada di perusahaan diyakini akan meningkatkan kinerja perusahaan karena dengan adanya kepemilikan manajerial maka para pimpinan perusahaan (direksi dan dewan komisaris) akan terdorong untuk melaksanakan tugasnya dengan baik dan melakukan pengawasan secara efisien (Brickley et al., 1988). Ketika perusahaan memiliki kepemilikan manajerial, maka dewan direksi dan komisaris juga merupakan bagian dari pemegang saham, sehingga mereka memiliki tujuan yang sama dengan para pemegang saham lainnya yaitu meningkatkan nilai perusahaan dan menurunkan risiko. Penelitian empiris oleh Jensen dan Murphy (1990) serta Chung dan Pruitt (1994) menemukan bahwa board's ownership mampu meningkatkan kinerja perusahaan. Selain itu, Chen et al. (1998) menyimpulkan bahwa kepemilikan manajerial mampu menurunkan risiko pasar. Selanjutnya, Capozza dan Seguin (2003) menyimpulkan bahwa perusahaan dengan proporsi insider ownership yang lebih tinggi cenderung untuk berinvestasi pada aset yang tidak berisiko dan menggunakan proporsi hutang yang lebih sedikit pada struktur modalnya, sehingga risiko total perusahaan cenderung menurun. Oleh karena itu, hipotesis 4 adalah kepemilikan manajerial berpengaruh negatif dan signifikan terhadap risiko perusahaan.

Konflik keagenan yang terjadi di perusahaan menyebabkan risiko yang dihadapi perusahaan semakin meningkat. Adanya komisaris independen pada perusahaan mampu untuk mengatasi masalah konflik keagenan, sehingga risiko yang dihadapi perusahaan lebih rendah jika perusahaan memiliki proporsi komisaris independen yang lebih tinggi (Tsorhe et al., 2011). Penelitian empiris menyatakan bahwa direksi independen merupakan faktor penting dalam kesuksesan perusahaan. Penelitian empiris menyimpulkan bahwa perusahaan yang memiliki rasio direksi independen yang tinggi menghadapi frekuensi tekanan keuangan yang lebih sedikit (Fathi dan Jean-Pierre, 2001). Selain itu, Daily dan Dalton (2003)menemukan bahwa perusahaan yang mempunyai direksi independen yang lebih banyak, memiliki kemungkinan kebangkrutan yang lebih kecil. Dalam tata kelola perusahaan, khususnya di Indonesia, diatur bahwa perusahaan harus memiliki komisaris independen minimal 30 persen. Komisaris independen dan direktur independen sama-sama merupakan anggota yang berasal dari luar perusahaan atau outsider. Mereka memiliki peran dan pengawasan yang hampir sama. Oleh karena itu, tingginya proporsi komisaris independen mencerminkan tata kelola perusahaan yang baik dan berpengaruh pada penurunan risiko perusahaan. Dengan demikian, hipotesis 5 adalah proporsi komisaris independen berpengaruh negatif dan signifikan terhadap risiko perusahaan

McDonald (2006) menjelaskan bahwa derivatif adalah suatu instrumen keuangan (atau secara sederhana, persetujuan diantara dua orang) yang mempunyai nilai yang dideterminasi oleh harga dari sesuatu yang lain. Derivatif juga dapat didefinisikan sebagai suatu instrumen keuangan yang nilainya tergantung pada (atau berasal dari) nilai-nilai variabel lain yang mendasarinya, dimana sering kali variabel yang mendasari derivatif adalah harga asset yang diperdagangkan (Hull, 2009). Perusahaan atau pelaku pasar menggunakan produk derivatif karena derivatif memberikan manfaat sebagai alat manajemen risiko (Ross et al., 2012; McDonald, 2006). Derivatif merupakan suatu alat bagi perusahaan dan para pengguna lainnya untuk 
menurunkan risiko. Derivatif adalah alat untuk mengubah eksposur risiko perusahaan. Dengan menggunakan derivatif perusahaan dapat menghilangkan ekposur risiko yang tidak diinginkan dan bahkan dapat mengubah eksposur ke dalam bentuk yang sangat berbeda. Ketika perusahaan mengurangi eksposur risiko dengan penggunaan derivatif, hal ini disebut sebagai hedging

Teori klasik mengenai keputusan pendanaan oleh Modigliani dan Miller (1963), mengungkapkan bahwa manajemen risiko perusahaan tidak relevan karena pemegang saham mampu untuk menciptakan portofolio saham yang well-diversified dalam asumsi pasar modal yang sempurna. Namun, pada dunia nyata hal ini tidak terjadi karena tidak ada pasar modal yang sempurna. Teori corporate hedging yang dikembangkan oleh Smith dan Stulz (1985) menyatakan bahwa pasar modal yang tidak sempurna menciptakan suatu kondisi bahwa hedging dibenarkan secara ekonomi.

Teori klasik mengenai keputusan pendanaan oleh Modigliani dan Miller (1963), mengungkapkan bahwa manajemen risiko perusahaan tidak relevan karena pemegang saham mampu untuk menciptakan portofolio saham yang well-diversified dalam asumsi pasar modal yang sempurna. Namun, pada dunia nyata hal ini tidak terjadi karena tidak ada pasar modal yang sempurna. Teori corporate hedging yang dikembangkan oleh Smith dan Stulz (1985) menyatakan bahwa pasar modal yang tidak sempurna menciptakan suatu kondisi bahwa hedging dibenarkan secara ekonomi. Penelitian oleh Guay (1999) menemukan bahwa perusahaan yang menggunakan derivatif untuk hedging, mengalami penurunan risiko perusahaan yang signifikan. Penggunaan derivatif dengan cara hedging, mampu menurunkan risiko perusahaan dengan mengurangi ekspektasi biaya financial distress dan menurunkan biaya pajak (Gatopoulos dan Loubergé, 2013). Oleh karena itu, jika perusahaan mampu mengelola risikonya dengan menggunakan produk derivatif melalui hedging, maka risiko perusahaan cenderung menurun. Dengan demikian, hipotesis 6 adalah penggunaan derivatif berpengaruh negatif dan signifikan terhadap risiko perusahaan

\section{METODE PENELITIAN}

Penelitian menggunakan rancangan kausalitas untuk membuktikan hubungan antara sebab dan akibat dari beberapa variabel. Penelitian ini dirancang untuk mengetahui pengaruh tingkat likuiditas, solvabilitas, profitabilitas, proporsi komisaris independen, kepemilikan manajerial dan penggunaan derivatif terhadap risiko perusahaan. Objek penelitian adalah risiko perusahaan pada perusahaan non keuangan yang terdaftar di indeks Kompas100 BEI tahun 2017.

Risiko perusahaan menjadi variabel terikat dalam penelitian ini. Likuiditas, solvabilitas, profitabilitas, proporsi komisaris independen, kepemilikan manajerial dan penggunaan derivatif merupakan variabel bebas dalam penelitian ini. Desain penelitian dalam penelitian ini dapat dicermati pada Gambar 1.

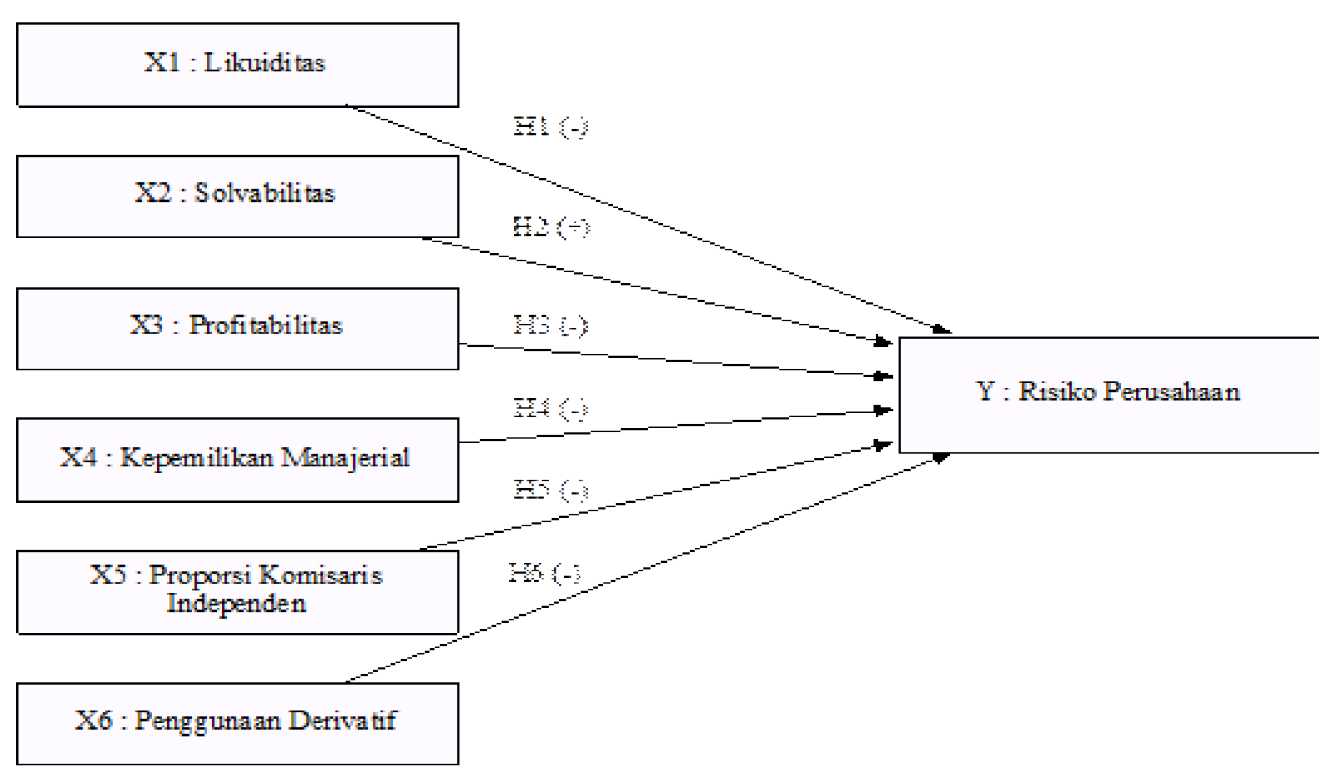

Gambar 1. Desain Penelitian 
Penelitian ini dilaksanakan di Indonesia yaitu pada perusahaan-perusahaan non-keuangan yang terdaftar di indeks Kompas 100 Bursa Efek Indonesia. Lokasi ini dipilih karena Bursa Efek Indonesia merupakan satu-satunya bursa efek di Indonesia dan semua perusahaan yang terdaftar di Indonesia melalui Bursa Efek Indonesia.

Seluruh data dalam penelitian ini merupakan data kuantitatif. Data kuantitatif merupakan data yang berbentuk angka. Data sekunder adalah data yang sudah dikumpulkan oleh pihak tertentu untuk tujuan lain (M. Saunders et al., 2016). Penelitian ini menggunakan data sekunder, dimana seluruh data seperti tingkat likuiditas, solvabilitas, profitabilitas, proporsi komisaris independen, kepemilikan manajerial dan penggunaan derivatif dapat diperoleh dari laporan keuangan tahunan perusahaan yang dipublikasikan pada website BEI. Sedangkan data risiko perusahaan dihitung setelah mengumpulkan data harga saham harian seluruh perusahaan melalui website yahoo finance.

Populasi dalam penelitian ini adalah perusahaan non-keuangan yang terdaftar di indeks Kompas 100 Bursa Efek Indonesia pada tahun 2017. Penelitian ini memiliki tujuan untuk menganalisis pengaruh likuiditas, solvabilitas, profitabilitas, proporsi komisaris independen, kepemilikan manajerial dan penggunaan derivative terhadap risiko perusahaan. Perusahaan yang melakukan tindakan hedging merupakan perusahaan yang bertindak sebagai pengguna derivative (McDonald, 2006). Populasi yang tepat untuk penelitian ini adalah perusahaan yang hanya bertindak sebagai pengguna derivatif. Perusahaan dalam industri finance atau keuangan tidak sesuai dengan kriteria ini, karena perusahaan tersebut dapat bertindak sebagai pengguna, penerbit dan juga market-makers (McDonald, 2006). Perusahaan non-keuangan yang terdaftar di indeks Kompas100 BEI berjumlah 85 perusahaan.

Teknik penentuan sampel dalam penelitian ini adalah purposive sampling method. Purposive sampling method adalah teknik pengambilan sampel berdasarkan kriteria yang ditentukan oleh peneliti. Kriteria pengambilan sampel yang digunakan dalam penelitian ini adalah (1) perusahaan non-keuangan yang sahamnya selalu muncul dalam indeks Kompas 100 pada periode pertama dan periode kedua tahun 2017 (2) perusahaan yang mempublikasikan laporan keuangan tahunan untuk tahun 2017. Berdasarkan kriteria yang telah ditentukan, maka diperoleh 74 perusahaan yang memenuhi kriteria sampel.

Risiko Perusahaan (Y) yang digunakan dalam penelitian ini adalah volatilitas returns saham harian Perusahaan Non-Keuangan yang terdaftar pada indeks Kompas 100 di BEI pada tahun 2017. Pengukuran ini digunakan mengacu pada penelitian terdahulu oleh Guay (1999) dan Bartram et al. (2009) yang mengatakan bahwa pengukuran risiko secara agregat dapat diukur dengan menggunakan volatilitas stock returns.

Likuiditas $\left(X_{1}\right)$ merupakan rasio yang menunjukkan kemampuan perusahaan untuk memenuhi kebutuhan jangka pendeknya. Tingkat liquidity perusahaan pada penelitian ini diukur dengan menggunakan current ratio, dimana dihitung dengan membagi aktiva lancar dengan hutang lancar pada perusahaan-perusahaan nonkeuangan yang terdaftar pada indeks Kompas100 di BEI pada tahun 2017. Skala data ini adalah data rasio.

Solvabilitas $\left(\mathrm{X}_{2}\right)$ adalah rasio yang mencerminkan seberapa jauh perusahaan dibiayai oleh hutang atau dana pinjaman. Tingkat leverage perusahaan dapat diukur dengan menggunakan debt to equity ratio yaitu dengan membagi hutang perusahaan dengan ekuitas perusahaan pada perusahaan-perusahaan non-keuangan yang terdaftar pada indeks Kompas100 di BEI pada tahun 2017. Skala data ini adalah data rasio.

Profitabilitas $\left(\mathrm{X}_{3}\right)$ merupakan rasio yang menunjukkan kemampuan perusahaan untuk menghasilkan laba bersih. Rasio Profitabilitas yang digunakan dalam penelitian ini adalah return on assets yang diperoleh dengan membagi laba bersih dengan total aset pada perusahaan-perusahaan nonkeuangan yang terdaftar pada indeks Kompas100 di BEI pada tahun 2017. Skala data ini adalah data rasio.

Kepemilikan Manajerial $\left(\mathrm{X}_{4}\right)$ adalah proporsi dari jumlah saham yang dimiliki oleh dewan direksi dan komisaris di perusahaan dibandingkan dengan jumlah total saham perusahaan pada perusahaanperusahaan non-keuangan yang terdaftar pada indeks Kompas100 di BEI pada tahun 2017. Proporsi ini diukur dengan membagi jumlah saham yang dimiliki oleh dewan direksi dan komisaris dengan jumlah total saham perusahaan. Skala data ini adalah data rasio.

Proporsi Komisaris Independen $\left(\mathrm{X}_{5}\right)$ adalah proporsi dari jumlah anggota komisaris independen 
dibandingkan dengan jumlah anggota dewan komisaris perusahaan pada perusahaan-perusahaan non-keuangan yang terdaftar pada indeks Kompas100 di BEI pada tahun 2017. Proporsi ini diukur dengan membagi jumlah komisaris independen perusahaan dengan jumlah total komisaris perusahaan. Skala data ini adalah data rasio.

Penggunaan derivatif $\left(\mathrm{X}_{6}\right)$ yang dimaksud dalam penelitian ini adalah penggunaan instrumen derivatif sebagai alat manajemen risiko oleh Perusahaan-perusahaan Non-Keuangan yang terdaftar pada indeks Kompas100 di BEI pada tahun 2017. Variabel ini merupakan variabel dummy, dimana bernilai 1 jika perusahaan menggunakan derivatif dan bernilai 0 jika perusahaan tidak menggunakan derivatif.

Teknik analisis data yang digunakan dalam penelitian ini adalah analisis deskriptif dan analisis regresi menggunakan program SPSS. Analisis data pertama yang dilakukan dalam penelitian ini adalah statistik deskriptif. Statistik deskriptif merupakan suatu metode analisis data yang digunakan untuk mendeskripsikan atau menggambarkan data yang telah terkumpul (Sugiyono, 2017). Statistik deskriptif dalam penelitian ini akan melakukan perhitungan rata-rata, standar deviasi, prosentase dari data sampel untuk seluruh variabel dengan data rasio.

Analisis data kedua yang dilakukan dalam penelitian ini adalah analisis inferensial. Analisis inferensial digunakan untuk menguji hipotesis yang diformulasikan dalam penelitian ini. Teknik analisis inferensial yang dilakukan dalam penelitian ini adalah analisis regresi linier berganda untuk menguji Hipotesis 1 sampai dengan Hipotesis 6 dengan menggunakan program SPSS. Persamaan regresi linier berganda dari model empirik penelitian ini dapat dituliskan dalam persamaan berikut:

$$
\begin{aligned}
& Y=a+b_{1} X_{1}+b_{2} X_{2}+b_{3} X_{3}+b_{4} X_{4}+b_{5} X_{5}+b_{6} X_{6}
\end{aligned}
$$

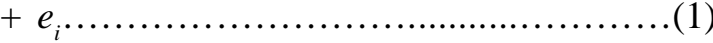

Keterangan:

$\mathrm{Y} \quad=$ Risiko Perusahaan

$\mathrm{X}_{1} \quad=$ Likuiditas

$\mathrm{X}_{2}=$ Solvabilitas

$\mathrm{X}_{3} \quad=$ Profitabilitas

$\mathrm{X}_{4} \quad=$ Kepemilikan Manajerial

$\mathrm{X}_{5} \quad=$ Proporsi Komisaris Independen

$\mathrm{X}_{6} \quad=$ Penggunaan Derivatif

a $\quad=$ Bilangan Konstanta

$\mathrm{b}_{1}-\mathrm{b}_{6}=$ Koefisien Regresi

$\mathrm{e}_{\mathrm{i}} \quad=$ Residual error

Penelitian ini menggunakan data sekunder, maka untuk menentukan ketepatan model perlu dilakukan pengujian atas beberapa asumsi klasik yang digunakan dalam penelitian ini. Pengujian asumsi klasik dilakukan dengan melakukan pengujian terhadap multikolonieritas, autokorelasi dan heteroskedastisitas. Sebelum pengujian asumsi klasik dilakukan, terlebih dahulu akan dilakukan pengujian normalitas errors. Pengujian normalitas bertujuan untuk mengetahui apakah dalam model regresi, variabel pengganggu atau residual memiliki distribusi normal. Hal ini dilakukan mengingat bahwa dalam model regresi, Uji t dan Uji F statistik mengasumsikan bahwa nilai residual mengikuti distribusi normal (Gujarati dan Porter, 2009).

\section{HASIL DAN PEMBAHASAN}

Analisis statistik deskriptif dilakukan untuk memberikan gambaran atau deskripsi mengenai variabel penelitian yang terdiri dari Risiko Perusahaan (Y), Likuiditas $\left(\mathrm{X}_{1}\right)$, Solvabilitas $\left(\mathrm{X}_{2}\right)$, Profitabilitas $\left(\mathrm{X}_{3}\right)$, Kepemilikan Manajerial $\left(\mathrm{X}_{4}\right)$, Proporsi Komisaris Independen $\left(\mathrm{X}_{5}\right)$ dan Penggunaan Derivatif $\left(\mathrm{X}_{6}\right)$ melalui nilai rata-rata (mean), nilai maksimum, nilai minimum dan standar deviasi. Statistik deskriptif selengkapnya dapat dilihat pada Tabel 1 .

Tabel 1. Statistik Deskriptif Variabel Penelitian

\begin{tabular}{llrrrr}
\hline & $\mathrm{N}$ & \multicolumn{1}{c}{ Minimum } & Maksimum & \multicolumn{1}{c}{ Rata-rata } & \multicolumn{2}{c}{ Standar Deviasi } \\
\hline $\mathrm{Y}$ & 74 & 1,04 & 5,67 & 2,21 & 0,91 \\
$\mathrm{X}_{1}$ & 74 & 0,43 & 7,86 & 2,23 & 1,80 \\
$\mathrm{X}_{2}$ & 74 & 0,06 & 13,58 & 1,67 & 2,66 \\
$\mathrm{X}_{3}$ & 74 & $-7,95$ & 37,06 & 6,28 & 8,07 \\
$\mathrm{X}_{4}$ & 74 & 0,00 & 8,37 & 0,31 & 1,20 \\
$\mathrm{X}_{5}$ & 74 & 0,20 & 0,83 & 0,43 & 0,14 \\
$\mathrm{X}_{6}$ & 74 & 0,00 & 1,00 & 0,49 & 0,50 \\
\hline
\end{tabular}

Sumber: Data sekunder diolah (2019) 
Tabel 1 menunjukkan bahwa jumlah data yang digunakan dalam penelitian ini berjumlah 74 poin data yang didapat dari jumlah sampel sebanyak 74 perusahaan. Berdasarkan Tabel 1, dapat diketahui bahwa risiko perusahaan yang terendah yaitu sebesar 1,04 yaitu pada Perusahaan Bumi Resources Tbk. Sedangkan yang tertinggi yaitu sebesar 5,67 yaitu pada Perusahaan Tiga Pilar Sejahtera FOOD Tbk. Hasil tersebut juga menunjukkan bahwa rata-rata risiko perusahaan non-keuangan yang terdaftar dalam Indeks Kompas 100 di BEI tahun 2017 adalah 2,21 dan standar deviasinya 0,91025.

Likuiditas terendah adalah 0,43 yaitu pada perusahan Eagle High Plantation Tbk. dan yang tertinggi adalah 7,86 yaitu pada perusahan Mitra Keluarga Karyasehat Tbk. Hasil tersebut juga menunjukkan bahwa likuiditas memiliki rata-rata yang positif yaitu 2,23 dan standar deviasi sebesar 1,80 .

Solvabilitas terendah adalah 0,06 yaitu pada perusahan Puradelta Lestari Tbk. dan yang tertinggi adalah 13,58 yaitu pada perusahan Tower Bersama Infrastructure Tbk. Hasil tersebut juga menunjukkan bahwa solvabilitas memiliki rata-rata yaitu 1,67 dan standar deviasi sebesar 2,66.

Profitabilitas terendah adalah -7,95 persen yaitu pada perusahan Garuda Indonesia Tbk. dan yang tertinggi adalah 37,06 persen yaitu pada perusahan Unilever Indonesia Tbk. Hasil tersebut juga menunjukkan bahwa profitabilitas memiliki rata-rata yaitu 6,28 persen dan standar deviasi sebesar 8,07.

Kepemilikan manajerial terendah sebesar 0 yang memiliki arti bahwa perusahaan tersebut tidak menerapkan program kepemilikan saham oleh manajemen perusahaan. Sedangkan yang tertinggi adalah 8,37 persen yaitu pada perusahan
Ramayana Lestari Sentosa Tbk. Hasil tersebut juga menunjukkan bahwa kepemilikan manajerial memiliki rata-rata yaitu 0,31 persen dan standar deviasi sebesar 1,20.

Proporsi komisaris independen terendah sebesar 0,20 yaitu pada perusahaan Semen Baturaja (Persero) Tbk. dan yang tertinggi adalah 0,83 yaitu pada perusahan Indika Energy Tbk. Hasil tersebut juga menunjukkan bahwa proporsi komisaris independen memiliki rata-rata yaitu 0,43 dan standar deviasi sebesar 0,14.

Penggunaan derivatif merupakan variabel dummy, sehingga nilai terendah yaitu 0 yang memiliki arti bahwa perusahaan tersebut tidak menggunakan instrumen derivatif sebagai alat manajemen risiko. Sedangkan yang tertinggi adalah 1 yang berarti bahwa perusahaan menggunakan instrumen derivatif sebagai alat manajemen risiko. Hasil tersebut juga menunjukkan bahwa penggunaan derivatif memiliki rata-rata yaitu 0,49 dan standar deviasi sebesar 0,50 .

Sebelum dilakukan pengujian terhadap hipotesis yang diajukan, terlebih dahulu dilakukan Uji Asumsi Klasik terhadap data yang digunakan. Uji Normalitas bertujuan untuk menguji sejauh mana distribusi data sampel berkorespondensi terhadap distribusi normal (Hair et al., 2014). Dalam model regresi, Uji $\mathbf{t}$ dan Uji F statistik mengasumsikan bahwa nilai residual mengikuti distribusi normal (Gujarati dan Porter, 2009). Pengujian normalitas data dalam studi ini dilakukan dengan metode Kolmogorov-Smirnov (K-S). Hasil uji normalitas pada Tabel 2 menunjukkan nilai asymp. Sig (2-tailed) sebesar $0,200(p>0,05)$. Ini mengindikasikan adanya distribusi data normal, sehingga data dapat digunakan untuk analisis regresi selanjutnya.

Tabel 2. Hasil Uji Normalitas

\begin{tabular}{llr}
\hline & & Unstandardized Residual \\
\hline $\mathrm{N}$ & & 74 \\
Normal Parameters & Mean & Mean \\
& Standard Deviation & 0,0000000 \\
Most Extreme & Absolute & 0,66922780 \\
Differences & Positive & 0,062 \\
Kolmogorov-Smirnov Z & Negative & 0,062 \\
Asymp. Sig. (2-tailed) & & $-0,048$ \\
\hline Sumber: Datasekure & 0,062 \\
\end{tabular}

Sumber: Data sekunder diolah (2019) 
Uji autokorelasi digunakan untuk menguji apakah dalam model regresi terdapat korelasi antara residual pada periode $\mathbf{t}$ dengan residual pada periode t-1 (sebelumnnya)(Utama, 2009). Hasil uji autokorelasi melalui nilai Durbin Watson adalah
1,785 (Tabel 3). Hasil ini menunjukkan bahwa tidak ada kesimpulan yang pasti data tidak mengandung gejala autokorelasi karena dL $(1,4577)<\mathrm{dw}(1,785)$ $<\mathrm{dU}$ (18013), sehingga layak digunakan hanya untuk memprediksi hubungan antar variabel.

Tabel 3. Hasil Uji Autokorelasi

\begin{tabular}{cccccc}
\hline Model & $R$ & $R$ Square & $\begin{array}{c}\text { Adjusted } R \\
\text { Square }\end{array}$ & $\begin{array}{c}\text { Std. Error of the } \\
\text { Estimate }\end{array}$ & $\begin{array}{c}\text { Durbin- } \\
\text { Watson }\end{array}$ \\
\hline 1 & $0,678^{\text {a }}$ & 0,459 & 0,411 & 0,698 & 1,785 \\
\hline
\end{tabular}

Sumber: Data sekunder diolah (2019)

Uji multikolinearitas bertujuan untuk menguji apakah model regresi ditemukan adanya korelasi antar variabel bebas / independen. Multikolinearitas dapat dilihat dari nilai tolerance atau variance inflation factor (VIF). Nilai cutoff yang umum dipakai untuk menunjukkan adanya multikulinearitas adalah nilai tolerance d" 0.10 atau sama dengan nilai VIF e" 10 . Jika nilai tolerance $>0,10$ atau VIF $<10$ dikatakan tidak ada multikolinearitas (Ghozali, 2013). Dari hasil uji pada Tabel 4 dapat dicermati bahwa model regresi yang terbentuk tidak menunjukkan gejala multikolinearitas. Ketiadaan gejala ini ditunjukkan dari nilai VIF $<10$ dan tolerance $>0,1$.

Tabel 4. Hasil Uji Multikolinearitas

\begin{tabular}{|c|c|c|}
\hline Variabel & Tolerance & VIF \\
\hline Likuiditas & 0,810 & 1,234 \\
\hline Solvabilitas & 0,893 & 1,119 \\
\hline Profitabilitas & 0,812 & 1,231 \\
\hline Kepemilikan Manajerial & 0,959 & 1,042 \\
\hline Proporsi Komisaris Independen & 0,903 & 1,107 \\
\hline Penggunaan Derivatif & 0,958 & 1,044 \\
\hline
\end{tabular}

Sumber: Data sekunder diolah (2019)

Uji heteroskedastisitas bertujuan untuk mengetahui apakah variabel yang dioperasikan sudah mempunyai varian yang sama (homogen) atau sebaliknya (heterogen). Model regresi yang baik adalah yang homokedastisitas atau tidak terjadi heteroskedastisitas. Uji heteroskedastisitas dilakukan dengan uji glejser. Jika nilai signifikansinya lebih besar dari 0,05 maka dikatakan model bebas dari heteorkedastisitas (Ghozali, 2013). Tabel 5 menunjukkan bahwa kelima variabel tidak menunjukkan nilai yang signifikan (probabilitas signifikan lebih besar dari 0,05). Jadi dapat disimpulkan bahwa tidak terjadi gejala heteroskedastisitas pada model.

Tabel 5. Hasil Uji Heteroskedastisitas

\begin{tabular}{lc}
\hline \multicolumn{1}{c}{ Variabel } & Sig. \\
\hline (Constant) & 0,331 \\
Likuiditas & 0,172 \\
Solvabilitas & 0,441 \\
Profitabilitas & 0,446 \\
Kepemilikan Manajerial & 0,399 \\
Proporsi Komisaris Independen & 0,144 \\
Penggunaan Derivatif & 0,751 \\
\hline
\end{tabular}

Sumber: Data sekunder diolah (2019)

Analisis regressi dengan menggunakan program SPSS dilakukan dalam penelitian ini untuk menganalisis bagaimana pengaruh likuiditas, solvabilitas, profitabilitas, kepemilikan manajerial, proporsi komisaris independen dan penggunaan derivatif terhadap risiko perusahaan pada perusahaan non keuangan yang terdaftar dalam indeks Kompas100 di BEI. Hasil analisis regresi 
linear berganda untuk pengujian hubungan antar

Tabel 6.

variabel dalam penelitian ini dapat dilihat pada

Tabel 6. Hasil Analisis Regresi Linear Berganda

\begin{tabular}{|c|c|c|c|c|c|c|}
\hline \multirow{2}{*}{\multicolumn{2}{|c|}{ Model }} & \multicolumn{2}{|c|}{$\begin{array}{l}\text { Unstandardized } \\
\text { Coefficients }\end{array}$} & \multirow{2}{*}{$\begin{array}{c}\begin{array}{c}\text { Standardized } \\
\text { Coefficients }\end{array} \\
\text { Beta }\end{array}$} & \multirow[t]{2}{*}{$\mathrm{t}$} & \multirow[t]{2}{*}{ Sig. } \\
\hline & & $B$ & Std. Error & & & \\
\hline \multicolumn{2}{|l|}{ (Constant) } & 2,302 & 0,318 & & 7,228 & 0,000 \\
\hline \multicolumn{2}{|l|}{ Likuiditas } & $-0,027$ & 0,051 & $-0,053$ & $-0,528$ & 0,599 \\
\hline \multicolumn{2}{|l|}{ Solvabilitas } & 0,113 & 0,032 & 0,332 & 3,492 & 0,001 \\
\hline \multicolumn{2}{|l|}{ Profitabilitas } & $-0,026$ & 0,011 & $-0,230$ & $-2,304$ & 0,024 \\
\hline \multicolumn{2}{|c|}{ Kepemilikan Manajerial } & 0,033 & 0,070 & 0,044 & 0,476 & 0,636 \\
\hline \multicolumn{2}{|c|}{$\begin{array}{l}\text { Proporsi Komisaris } \\
\text { Independen }\end{array}$} & 0,801 & 0,618 & 0,123 & 1,297 & 0,199 \\
\hline \multicolumn{2}{|c|}{ Penggunaan Derivatif } & $-0,864$ & 0,166 & $-0,478$ & $-5,207$ & 0,000 \\
\hline R Square & $=0,459$ & & & & & \\
\hline Adjusted R Square & $=0,411$ & & & & & \\
\hline $\mathrm{F}$ & $=9,492$ & & & & & \\
\hline Sig & $=0,000$ & & & & & \\
\hline
\end{tabular}

Sumber: Data sekunder diolah (2019)

Berdasarkan hasil analisis pada Tabel 6 dapat disusun persamaan regresi linear sebagai berikut:

$$
\begin{array}{r}
Y= \\
2,302-0,053 X_{1}+0,332 X_{2}-0,230 X_{3}+0,044 \\
X_{4}+0,123 X_{5}-0,478 X_{5}+\text { e.................. (2) }
\end{array}
$$

Persamaan regresi tersebut dapat diuraikan sebagai berikut. Pertama, koefisien regresi untuk likuiditas adalah $-0,053$ ( $\mathrm{p}>0,10)$, sebagai indikasi bahwa setiap peningkatan likuiditas sebesar 1 , maka risiko perusahaan akan menurun sebesar 0,057, dengan asumsi variabel lainnya konstan. Kedua, koefisien regresi untuk solvabilitas adalah 0,332 $(\mathrm{p}<0,10)$, sebagai indikasi bahwa setiap peningkatan solvabilitas sebesar 1 , maka risiko perusahaan akan meningkat sebesar 0,332, dengan asumsi variabel lainnya konstan. Ketiga, koefisien regresi untuk profitabilitas adalah $-0,230(\mathrm{p}<0,10)$, sebagai indikasi bahwa setiap peningkatan profitabilitas sebesar 1 persen, maka risiko perusahaan akan menurun sebesar 0,230, dengan asumsi variabel lainnya konstan. Keempat, koefisien regresi untuk kepemilikan manajerial adalah 0,044 ( $\mathrm{p}>0,10)$, sebagai indikasi bahwa setiap peningkatan kepemilikan manajerial sebesar 1 , maka risiko perusahaan akan meningkat sebesar 0,044, dengan asumsi variabel lainnya konstan. Kelima, koefisien regresi untuk proporsi komisaris independen adalah $0,123$ ( $p>0,10)$, sebagai indikasi bahwa setiap peningkatan proporsi komisaris independen sebesar 1 , maka risiko perusahaan akan meningkat sebesar
0,123 , dengan asumsi variabel lainnya konstan. Keenam, koefisien regresi untuk penggunaan derivatif adalah $-0,478(\mathrm{p}<0,10)$, sebagai indikasi bahwa ketika perusahaan menggunakan derivatif sebagai alat manajemen risiko perusahaan, maka perusahaan tersebut cenderung memiliki tingkat risiko 0,478 lebih rendah. Hasil analisis menunjukkan nilai koefisien determinasi $\left(\mathrm{R}^{2}\right)$ sebesar 0,411 $(\mathrm{p}<0,10)$ yang berarti sebesar 41,1 persen variasi risiko perusahaan dijelaskan oleh variasi dari likuiditas, solvabilitas, profitabilitas, kepemilikan manajerial, proporsi komisaris independen dan penggunaan derivatif, sedangkan sisanya dijelaskan oleh variabel diluar model.

Hasil analisis menunjukkan bahwa variabel likuiditas memiliki koefisien regresi bertanda positif sebesar -0,053 dengan $p>0,10$. Hal ini berarti bahwa likuiditas tidak berpengaruh secara signifikan terhadap risiko perusahaan pada perusahaan nonkeuangan yang terdaftar pada indeks Kompas 100 di BEI. Hasil ini tidak mendukung hipotesis pertama $\left(\mathrm{H}_{1}\right)$ yang menyatakan bahwa likuiditas berpengaruh negatif signifikan terhadap risiko perusahaan. Likuiditas berpengaruh negatif namun tidak signifikan pada peningkatan atau penurunan risiko perusahaan.

Tanda negatif koefisien regresi likuiditas menunjukkan bahwa ketika suatu perusahaan memiliki tingkat likuiditas yang lebih tinggi, maka terjadi penurunan pada risiko perusahaan. Semakin meningkatnya tingkat likuiditas suatu perusahaan, 
maka perusahaan memiliki kemampuan yang lebih baik untuk memenuhi kebutuhan jangka pendeknya. Perusahaan yang memiliki tingkat likuiditas yang tinggi, menunjukkan perusahaan tersebut tidak memiliki masalah keuangan, sehingga risiko perusahaan akan menurun. Namun, hasil yang tidak signifikan dalam penelitian ini tidak mendukung temuan penelitian yang terdahulu oleh Biase dan D'Apolito (2012) yang membuktikan bahwa likuiditas berpengaruh negatif dan signifikan terhadap risiko perusahaan. Hal ini kemungkinan terjadi karena likuiditas bukanlah faktor pendorong yang kuat dalam mempengaruhi risiko perusahaan pada perusahaan non-keuangan indeks Kompas100 di BEI.

Hasil analisis menunjukkan bahwa variabel solvabilitas memiliki koefisien regresi bertanda positif sebesar $0,332(\mathrm{p}<0,10)$. Arah yang positif menunjukkan bahwa semakin tinggi tingkat solvabilitas suatu perusahaan, maka risiko perusahaan cenderung meningkat. Hasil penelitian ini mendukung hipotesis kedua $\left(\mathrm{H}_{2}\right)$ yang menyatakan bahwa solvabilitas berpengaruh positif signifikan terhadap risiko perusahaan pada perusahaan non-keuangan yang terdaftar pada indeks Kompas 100 di BEI. Hal ini berarti peningkatan atau penurunan solvabilitas berpengaruh terhadap peningkatan atau penurunan risiko perusahaan.

Salah satu pengukuran kinerja keuangan adalah dilihat melalui rasio solvabilitas. Tingkat rasio solvabilitas menunjukkan seberapa besar perusahaan menggunakan dana pinjaman untuk membiayai aktiva yang dimiliki perusahaan. Tingkat solvabilitas yang tinggi, mencerminkan perusahaan tersebut memiliki tingkat hutang yang tinggi. Tingkat hutang yang tinggi meningkatkan biaya financial distress perusahaan yang berakibat pada peningkatan risiko yang dihadapi perusahaan. Semakin tinggi tingkat solvabilitas perusahaan maka risiko perusahaan cenderung meningkat. Hasil penelitian ini mendukung secara teoritis bahwa solvabilitas dan risiko perusahaan memiliki hubungan yang negatif. Temuan ini juga mendukung hasil penelitian yang dilakukan oleh Mandelker dan Rhee (1984) dan Biase dan D‘Apolito (2012).

Hasil analisis menunjukkan bahwa variabel profitabilitas memiliki koefisien regresi bertanda negatif sebesar $-0,230(p<0,10)$. Arah yang negatif menunjukkan bahwa semakin tinggi tingkat profitabilitas suatu perusahaan, maka risiko perusahaan cenderung menurun. Hasil penelitian ini mendukung hipotesis ketiga $\left(\mathrm{H}_{3}\right)$ yang menyatakan bahwa profitabilitas berpengaruh negatif signifikan terhadap risiko perusahaan pada perusahaan nonkeuangan yang terdaftar pada indeks Kompas100 di BEI. Hal ini berarti peningkatan atau penurunan profitabilitas berpengaruh terhadap peningkatan atau penurunan risiko perusahaan.

Pengukuran kinerja keuangan penting lainnya adalah dilihat melalui rasio profitabilitas. Tingkat rasio profitabiltas menunjukkan kemampuan suatu perusahaan untuk menghasilkan laba bersih. Perusahaan yang mampu menghasilkan laba bersih yang positif, menunjukkan perusahaan tersebut mampu untuk berinvestasi dengan baik dan menekan biaya operasional dengan efektif. Selain itu, tingginya tingkat rasio profitabilitas mencerminkan perusahaan tidak memiliki permasalahan keuangan yang signifikan. Oleh karena itu, perusahaan yang memiliki tingkat profitabilitas tinggi, cenderung memiliki risiko yang lebih rendah. Hasil penelitian ini mendukung secara teoritis bahwa profitabilitas berpengaruh secara negatif terhadap risiko perusahaan. Temuan ini juga mendukung hasil penelitian yang dilakukan oleh Chun dan Meharani (1999) dan Biase dan D‘Apolito (2012).

Hasil analisis menunjukkan bahwa variabel kepemilikan manajerial memiliki koefisien regresi bertanda positif sebesar $0,044(p>0,10)$. Hal ini menunjukkan bahwa kepemilikan manajerial tidak berpengaruh secara signifikan terhadap risiko perusahaan pada perusahaan non keuangan yang terdaftar pada indeks Komps100 di BEI. Hasil ini tidak mendukung hipotesis keempat $\left(\mathrm{H}_{4}\right)$ yang menyatakan bahwa kepemilikan manajerial berpengaruh negatif signifikan terhadap risiko perusahaan. Penelitian ini menemukan bahwa kepemilikan manajerial berpengaruh positif dan tidak signifikan terhadap risiko perusahaan.

Secara teoritis dan hasil penelitian terdahulu, telah disusun hipotesis bahwa kepemilikan manajerial berpengaruh secara negatif dan signifikan terhadap risiko perusahaan. Namun, hasil penelitian yang dilakukan pada perusahaan non-keuangan yang terdaftar dalam indeks Kompas 100 di BEI menunjukkan bahwa semakin tinggi tingkat kepemilikan manajerial perusahaan, maka ada kecenderungan risiko perusahaan meningkat. Hal ini kemungkinan disebabkan karena sebagian besar perusahaan nonkeuangan yang terdaftar dalam indeks Kompas 100 di BEI belum menerapkan program kepemilikan manajerial. Dari 74 perusahaan, hanya 28 perusahaan yang menerapkan program ini. Oleh karena itu, kepemilikan manajerial bukan merupakan faktor pendorong yang kuat bagi perusahaan-perusahaan ini untuk mampu menurunkan 
risiko perusahaan. Hasil penelitian ini menemukan adanya hubungan positif yang tidak signifikan antara kepemilikan manajerial dan risiko perusahaan, dimana hasil ini tidak mendukung penelitian terdahulu oleh Chen et al. (1998) dan Capozza dan Seguin (2003).

Hasil analisis menunjukkan bahwa variabel proporsi komisaris independen memiliki koefisien regresi bertanda positif sebesar $0,123(\mathrm{p}>0,10)$. Hal ini menunjukkan bahwa proprosi komisaris independen tidak berpengaruh secara signifikan terhadap risiko perusahaan non-keuangan yang terdaftar di indeks Kompas100 di BEI. Hasil ini tidak mendukung hipotesis ketiga $\left(\mathrm{H}_{5}\right)$ yang menyatakan bahwa proporsi komisaris independen berpengaruh negatif signifikan terhadap risiko perusahaan. Proporsi komisaris independen berpengaruh positif dan tidak signifikan terhadap risiko perusahaan.

Penerapan good corporate governance mechanism dapat dilihat dari proporsi komisaris independen pada suatu perusahaan. Adanya komisaris independen pada suatu perusahaan, bermanfaat dalam mengatasi masalah konflik keagenan, sehingga perusahaan memiliki tingkat risiko yang lebih rendah. Namun, penelitian ini mendapatkan hasil bahwa penerapan good corporate governance oleh perusahaan, dengan meningkatkan proporsi komisaris independen, belum mampu untuk menurunkan risiko perusahaan. Hal ini kemungkinan besar disebabkan karena adanya faktor lain yang memiliki pengaruh lebih besar terhadap risiko perusahaan seperti solvabilitas, profitabilitas dan penerapan manajemen risiko. Hasil yang tidak signifikan pada penelitian ini tidak mendukung hasil penelitian terdahulu oleh Daily dan Dalton (2003) dan Tsorhe et al. (2011), yang menunjukkan bahwa proporsi komisaris independen berpengaruh negatif dan signifikan terhadap risiko perusahaan.

Hasil analisis menunjukkan bahwa variabel penggunaan derivatif memiliki koefisien regresi bertanda negatif sebesar $-0,478(\mathrm{p}<0,10)$. Arah yang negatif menunjukkan bahwa perusahaan yang menggunakan derivatif sebagai instrumen manajemen risiko, cenderung memiliki risiko yang lebih rendah. Hasil penelitian ini mendukung hipotesis kedua $\left(\mathrm{H}_{6}\right)$ yang menyatakan bahwa penggunaan derivatif berpengaruh negatif signifikan terhadap risiko perusahaan pada perusahaan nonkeuangan yang terdaftar pada indeks Kompas100 di BEI. Hal ini berarti penggunaan derivatif berpengaruh terhadap penurunan risiko perusahaan.

Salah satu penerapan manajemen risiko perusahaan adalah dengan menggunakan produk derivatif sebagai alat manajemen risiko dengan hedging. Penggunaan derivatif dengan cara hedging, memiliki manfaat untuk menurunkan risiko perusahaan dengan mengurangi ekspektasi biaya financial distress dan menurunkan biaya pajak. Perusahaan pengguna derivatif terbukti memiliki tingkat risiko yang lebih rendah. Hasil penelitian ini mendukung secara teoritis bahwa penggunaan derivatif dan risiko perusahaan memiliki hubungan yang negatif. Temuan ini juga mendukung hasil penelitian yang dilakukan oleh Gatopoulos dan Loubergé (2013).

\section{SIMPULAN}

Beberapa kesimpulan dapat diperoleh dari hasil analisis data dan pembahasan. Pertama, penelitian ini menemukan bahwa faktor yang paling berpengaruh terhadap risiko perusahaan pada perusahaan non-keuangan yang terdaftar pada indeks Kompas 100 di BEI tahun 2017 adalah solvabilitas, profitabilitas dan penggunaan derivatif. Sedangkan ketiga faktor lainnya yaitu likuiditas, kepemilikan manajerial dan proporsi komisaris independen tidak berpengaruh secara signifikan. Tingkat solvabilitas perusahaan memiliki pengaruh yang positif dan signifikan terhadap risiko perusahaan dengan tingkat signifikansi 10 persen. Tingkat profitabilitas perusahaan memiliki pengaruh yang negatif dan signifikan terhadap risiko perusahaan dengan tingkat signifikansi 5 persen. Penggunaan derivatif memiliki pengaruh yang negatif dan signifikan terhadap risiko perusahaan dengan tingkat signifikansi 10 persen.

Hasil penelitian mampu memberikan saran pada perusahaan non-keuangan di BEI bahwa ketika perusahaan memiliki tingkat solvabilitas yang terlalu tinggi, maka tingkat risiko perusahaan akan meningkat. Perusahaan penting untuk memperhatikan tingkat profitabilitas, karena tingkat profitabilitas yang lebih tinggi akan cenderung mengurangi risiko perusahaan. Perusahaan juga penting untuk mempertimbangkan penggunaan derivatif sebagai instrumen manajemen risiko perusahaan, karena penggunaan derivatif terbukti berpengaruh negatif signifikan terhadap risiko perusahaan. Penelitian di masa mendatang, penting untuk memperhatikan faktor eksternal perusahaan seperti keadaan perekonomian dalam mempengaruhi risiko perusahaan karena penelitian ini hanya fokus pada kondisi internal perusahaan.

\section{REFERENSI}

Bartram, S. M., Brown, G. W., \& Conrad, J. S. (2009). The Effects of Derivatives on Firm 
Risk and Value. Ssrn, 46(4), 967-999. https:// doi.org/10.2139/ssrn.1342771

Beaver, W., Kettler, P., \& Scholes, M. (1970). The Association Between Market Determined and Accounting Determined Risk Measures. The Accounting Review, 45(4), 654-682.

Biase, P. di, \& D'Apolito, E. (2012). The Determinants of Systematic Risk in the Italian Banking System: A Cross-Sectional Time Series Analysis. International Journal of Economics and Finance, 4(11), 152-164. https://doi.org/ 10.5539/ijef.v4n11p152

Borokhovich, K. A., Brunarski, K. R., \& Simkins, B. J. (2004). Board Composition and Corporate Use Of Interest Rate Derivatives. The Journal of Financial Research, 27(2), 199-216.

Brealey, R.A., Myers, S.C., Marcus, A. . (2014). Fundamentals of Corporate Finance (8th ed.). New York: McGraw-Hill Company.

Brickley, J. A., Lease, R. C., \& Smith, C. W. (1988). Ownership structure and voting on antitakeover amendments. Journal of Financial Economics, 20(C), 267-291. https://doi.org/ 10.1016/0304-405X(88)90047-5

Brigham, E.F., \& Daves, P. . (2007). Intermediate Financial Management (9th ed.). USA: Thomson Higher Education.

Capozza, D. R., \& Seguin, P. J. (2003). Inside Ownership, Risk Sharing and Tobin's q-Ratios: Evidence from REITs. Real Estate Economics, 31(3), 367-404. https://doi.org/10.1111/15406229.00070

Chen, C. L., Fan, H. S., \& Yang, Y. M. (2014). The effects of corporate governance and accounting rule changes on derivatives usage. In Review of Derivatives Research (Vol. 17). https:// doi.org/10.1007/s11147-014-9100-5

Chen, C. R., Steiner, T. L., \& Whyte, A. M. (1998). Risk-taking behavior and management ownership in depository institutions. Journal of Financial Research, 21(1), 1-16. https:// doi.org/10.1111/j.1475-6803.1998.tb00266.x

Chun, L. S., \& Ramasamy, M. (1989). Accounting variables as determinants of systematic risk in Malaysian common stocks. Asia Pacific Journal of Management, 6(2), 339-350. https://doi.org/10.1007/BF01733773

Chung, K. H., \& Pruitt, S. W. (1994). Simple of Tobin' s Approximation q. Venture Capital, 23(3), 70-74.

Daily, C. M., \& Dalton, D. A. N. R. (2003). Introduction To Special Topic Forum Corporate Governance: Decades of Dialogue and Data.
(B) Academy Oí Management Review, 28(3), 371-382.

Fahmi, I. (2011). Analisis Laporan Keuangan. Lampulo: ALFABETA.

Fathi, E., \& Jean-Pierre, G. (2001). Financial distress and corporate governance: an empirical analysis. Corporate Governance: The International Journal of Business in Society, 1(1), 15-23. Retrieved from http://dx.doi.org/10.1108/ 14720700110389548

FCGI. (2016). Corporate Governance: Tata Kelola Perusahaan. Jakarta: Prentice Hall.

Gatopoulos, G., \& Loubergé, H. (2013). Combined use of foreign debt and currency derivatives under the threat of currency crises: The case of Latin American firms. Journal of International Money and Finance, 35, 54-75. https://doi.org/10.1016/j.jimonfin.2013.01 .004

Ghozali, I. (2013). Aplikasi Analisis Multivariate dengan Program IBM SPSS 21 (7th ed.). Semarang: Badan Penerbit Universitas Diponegoro.

Guay, W. R. (1999). The impact of derivatives on firm risk: An empirical examination of new derivative users. Journal of Accounting and Economics, 26(1-3), 319-351. https://doi.org/ 10.1016/S0165-4101(98)00032-9

Gujarati, D. N., \& Porter, D. C. (2009). Basic Econometrics (5th ed.). Boston: McGraw-Hill International Edition.

Hair Jr, J. F., Hult, G. T. M., Ringle, C. M., \& Sarstedt. (2014). A Primer on Partial Lest Squares Structural Equation Modelling. Los Angeles: Sage Publication.

Hanafi, M. . (2014). Manajemen Risiko (3rd ed.). Yogyakarta: UPP STIM YKPN.

Hardwick, P., \& Adams, M. (1999). The determinants of financial derivatives use in the United Kingdom life insurance industry. Abacus, 35(2), 163-184. https://doi.org/10.1111/ 1467-6281.00039

Hull, J. . (2009). Options, Futures, and other Derivatives (7th ed.). USA: Pearson Education, Inc.

Jensen, M. C., \& Murphy, K. J. (1990). Performance Pay and Top-Management Incentives. Journal of Political Economy, 98(2).

Lantara, I. W. . (2010). A Survey on the Use of Derivatives in Indonesia. Gajah Mada International Journal of Business, 12(3), 295-323.

Mandelker, G. N., \& Rhee, G. (1984). The Impact of the Degrees of Operating and Financial 
Leverage on Systematic Risk of Common Stock Author ( s ): Gershon N . Mandelker and S . Ghon Rhee Source/ : The Journal of Financial and Quantitative Analysis , Vol . 19, No . 1 ( Mar ., 1984 ), pp . 45. The Journal of Financial and Quantitative Analysis, 19(1), 45-57.

McDonald, R. . (2006). Derivatives Markets (2nd ed.). USA: Pearson Education, Inc.

Modigliani, F., \& Miller, M. H. (1963). Income Taxes and the Cost of Capital. The American Economic Review, 53(3), 433-443.

Mulyadi. (2008). Sistem Akuntansi (4th ed.). Jakarta: Salemba Empat.

Munawir. (2010). Analisis Laporan Keuangan (4th ed.). Yogyakarta: Liberty.

OECD. (2014). Risk Management and Corporate Governance. OECD Publishing.

Osuoha, J. I. (2013). Financial Engineering, Corporate Goverance and Nigeria Economic Development. Journal of Financial Risk Management, 02(04), 61-66. https://doi.org/ $10.4236 / \mathrm{jfrm} .2013 .24010$

Ross, S., Westerfield, R., \& Jaffe, J. (2012). Corporate Finance (10th ed.). USA: The McGraw-Hill Companies.

Saunders, A., \& Cornett, M. . (2014). Financial Institution Management/ : A Risk Management Approach. New York: Mc Graw Hill.

Saunders, M., Lewis, F., \& Thornhil, A. (2016). Research Methods for Business Students. Italy: Pearson Education.
Smith, C. W., \& Stulz, R. M. (1985). The Determinants of Firms' Hedging Policies. Journal of Financial and Quantitative Analysis, 20(4), 36.

Subramanian, T., \& Paramasivan, C. (2009). Financial Management. India: New Age International (P) Limited.

Sugiyono. (2017). Metode Penelitian Kuantitatif, Kualitatif dan $R \& D$. Bandung: Alfabeta.

Trinh, T. H., Duyen, T. T. T., \& Thao, N. T. (2015). The Impact of Corporate Governance on Financial Risk in Vietnamese Commercial Banks. International Journal of Economics and Finance, 7(7), 123-130. https://doi.org/ 10.5539/ijef.v7n7p123

Tsorhe, J., Aboagye, A., \& Kyereboah-Coleman, A. (2011). Corporate Governance and Bank Risk Management in Ghana. University of Ghana Business School, 1-22. Retrieved from http://www.csae.ox.ac.uk/conferences/ 2011-EDiA/papers/651-Aboagye.pdf

Utama, M. . (2009). Aplikasi Analisis Kuantitatif (3rd ed.). Denpasar: Fakultas Ekonomi Universitas Udayana.

Van Horne, J. C., Jr., W., \& J.M. (2008). Fundamentals of Financial Management (13th ed.). England: Pearson Education Limited.

Welker, M. (1995). Disclosure policy, information assymetry and liquidity in markets. Contemporary Accounting Research, 11(2), 801-827. 